\title{
RESEARCH
}

Open Access

\section{In vitro study of cartilage tissue engineering using human adipose-derived stem cells induced by platelet-rich plasma and cultured on silk fibroin scaffold}

Imam Rosadi ${ }^{1,2^{*}+}$ (D), Karina Karina ${ }^{2,3,4 \dagger}$, lis Rosliana ${ }^{2}$, Siti Sobariah², Irsyah Afini ${ }^{2}$, Tias Widyastuti ${ }^{2}$ and Anggraini Barlian ${ }^{1+}$

\begin{abstract}
Background: Cartilage tissue engineering is a promising technique for repairing cartilage defect. Due to the limitation of cell number and proliferation, mesenchymal stem cells (MSCs) have been developed as a substitute to chondrocytes as a cartilage cell-source. This study aimed to develop cartilage tissue from human adipose-derived stem cells (ADSCs) cultured on a Bombyx mori silk fibroin scaffold and supplemented with 10\% platelet-rich plasma (PRP).
\end{abstract}

Methods: Human ADSCs and PRP were characterized. A silk fibroin scaffold with $500 \mu \mathrm{m}$ pore size was fabricated through salt leaching. ADSCs were then cultured on the scaffold (ADSC-SS) and supplemented with 10\% PRP for 21 days to examine cell proliferation, chondrogenesis, osteogenesis, and surface marker expression. The messenger ribonucleic acid (mRNA) expression of type 2 collagen, aggrecan, and type 1 collagen was analysed. The presence of type 2 collagen confirming chondrogenesis was validated using immunocytochemistry. The negative and positive controls were ADSC-SS supplemented with 10\% foetal bovine serum (FBS) and ADSC-SS supplemented with commercial chondrogenesis medium, respectively.

Results: Cells isolated from adipose tissue were characterized as ADSCs. Proliferation of the ADSC-SS PRP was significantly increased $(p<0.05)$ compared to that of controls. Chondrogenesis was observed in ADSC-SS PRP and was confirmed through the increase in glycosaminoglycans (GAG) and transforming growth factor- $\beta 1$ (TGF- $\beta 1$ ) secretion, the absence of mineral deposition, and increased surface marker proteins on chondrogenic progenitors. The mRNA expression of type 2 collagen in ADSC-SS PRP was significantly increased $(p<0.05)$ compared to that in the negative control on days 7 and 21; however, aggrecan was significantly increased on day 14 compared to the controls. ADSC-SS PRP showed stable mRNA expression of type 1 collagen up to 14 days and it was significantly decreased on day 21. Confocal analysis showed the presence of type 2 collagen in the ADSC-SS PRP and positive control groups, with high distribution outside the cells forming the extracellular matrix (ECM) on day 21.

Conclusion: Our study showed that ADSC-SS with supplemented 10\% PRP medium can effectively support chondrogenesis of ADSCs in vitro and promising for further development as an alternative for cartilage tissue engineering in vivo.

Keywords: Chondrogenesis of ADSCS, Salt-leached scaffold, Type 2 collagen, Type 1 collagen, Aggrecan

\footnotetext{
* Correspondence: imam.rosadi@hayandra.com

${ }^{\dagger}$ Imam Rosadi, Karina Karina and Anggraini Barlian contributed equally to this

work.

${ }^{1}$ School of Life Sciences and Technology, Institut Teknologi Bandung,

Bandung, West Java, Indonesia

${ }^{2}$ HayandraLab, Yayasan Hayandra Peduli, Jakarta, DKI Jakarta, Indonesia

Full list of author information is available at the end of the article
}

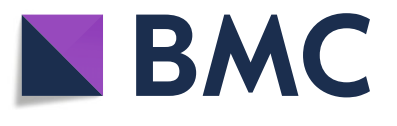

(c) The Author(s). 2019 Open Access This article is distributed under the terms of the Creative Commons Attribution 4.0 International License (http://creativecommons.org/licenses/by/4.0/), which permits unrestricted use, distribution, and reproduction in any medium, provided you give appropriate credit to the original author(s) and the source, provide a link to the Creative Commons license, and indicate if changes were made. The Creative Commons Public Domain Dedication waiver (http://creativecommons.org/publicdomain/zero/1.0/) applies to the data made available in this article, unless otherwise stated. 


\section{Background}

Cartilage tissue engineering is considered as a solution for repairing the cartilage defect such as microtia and ostheoarthritis. Cartilage tissue engineering involves use of cells, bioactive factors, and scaffolds. Ideally, chondrocytes are the cell source for cartilage. However, due to their limited number and low proliferation, mesenchymal stem cells (MSCs) have been developed as a substitute to chondrocytes as a cartilage cell source [1]. Adipose-derived stem cells (ADSCs) are multipotent MSCs that can be differentiated into several cell types including chondrocytes [2]. Several studies reported that foetal bovine serum (FBS) supplemented with bioactive factors including transforming growth factor-beta (TGF- $\beta$ ) induces chondrogenesis of ADSCs [3, 4]. However, FBS is less preferred in cartilage tissue engineering because of its animal origin and the possibility of contaminants, such as prions and inflammatory reactions [5]. Human platelet-rich plasma (PRP) is also used as a substitute for FBS to increase cell proliferation [6, 7]. PRP contains more than 1100 proteins [8] and has various growth and differentiation factors, including TGF- $\beta 1$, which regulates chondrogenesis $[6,7,9]$. Thus, in addition to replacing FBS as a proliferative agent, PRP can also induce chondrogenesis of ADSCs [8].

The other component of tissue engineering is the scaffold. Scaffolds act as a skeletal structure for cell attachment [10]. Silk fibroin is a candidate scaffold for cartilage tissue engineering based on its strength, porosity, biodegradability, biocompatibility, and support for cell proliferation and differentiation [10-12]. Silk fibroin scaffolds can be fabricated into 3D structures with various pore sizes and pore connectivity to regulate nutrient transport [11]. Our previous study showed that the $500 \mu \mathrm{m}$ pore size was the best for chondrogenesis using ADSCs on silk fibroin scaffolds compared to the $300 \mu \mathrm{m}$ and $100 \mu \mathrm{m}$ pore sizes [13]. During chondrogenesis, ADSCs cultured on silk fibroin scaffolds synthesized glycosaminoglycans (GAG), type 2 collagen, and aggrecan, as chondrocyte biomarkers $[10,11]$.

The GAG are classified as chondroitin sulphates (CS), dermatan sulphates (DS), keratan sulphates (KS), and heparan sulphates (HS). KS and CS bind to aggrecan and interact with type 2 collagen in chondrocytes [14]. Furthermore, as osteogenesis usually proceeds through chondrogenesis, both processes need to be observed in a study to confirm the differentiation process that occurs. Type 1 collagen expression and mineralization are signs of osteogenic differentiation. However, chondrogenesis and osteogenesis show a negative feedback that makes it important to confirm and evaluate osteogenesis-related genes in studies on chondrogenic induction in cartilage tissue engineering [15]. This study aims to investigate the chondrogenesis of ADSCs cultured on silk fibroin scaffolds with a $500 \mu \mathrm{m}$ pore size in PRP-supplemented medium.

\section{Methods}

\section{Silk fibroin fabrication}

Silk fibroin scaffolds were fabricated as described previously $[13,16]$. Silk fibroin obtained from Bombyx mori cocoons was reconstructed into scaffolds by a salt leaching method. Degumming of silk fibroin was performed by immersion in $0.05 \% \mathrm{Na}_{2} \mathrm{CO}_{3}$ solution. Silk fibroin was then diluted with $8 \mathrm{wt} \% \mathrm{CaCl}_{2}$ formic acid solution and reconstructed into scaffolds using $\mathrm{NaCl}$ with $\sim 500 \mu \mathrm{m}$ particle size to form $500 \mu \mathrm{m}$ pores. The mixture was then immersed in $70 \%$ alcohol and washed in distilled water for 3 days to remove the salt residues. The silk fibroin scaffolds were cut into $5 \mathrm{~mm} \times 5 \mathrm{~mm}$ pieces with $1 \mathrm{~mm}$ thickness and were sterilized in an autoclave for 15 min at $121^{\circ} \mathrm{C}$.

\section{Isolation, culture, and expansion of ADSCs}

The stromal vascular fraction (SVF) was isolated from lipoaspirates of four healthy patients using an enzymatic method which was H-Remedy enzyme patented by Yayasan Hayandra Peduli (patent number registration IDP000055609). Lipoaspirates digested by H-Remedy enzyme which incubated for $1 \mathrm{~h}$ at $37^{\circ} \mathrm{C}, 300 \mathrm{rpm}$. After incubation, to inactivate the enzyme, the digested lipoaspirates were added low-glucose $(1 \mathrm{~g} / \mathrm{L})$ Dulbecco's modified Eagle's medium (DMEM) containing $4 \mathrm{mML}$-glutamine (Gibco, USA) followed by centrifugation for $5 \mathrm{~min}$ at $600 \times$ g. Then, the supernatant was discarded. The pellet SVF was diluted in saline solution. The cell number and viability was counted by trypan blue staining which were calculated per $10 \mathrm{~mL}$ of adipose tissue digested.

Isolated cells were cultured in basic growth medium containing low glucose $(1 \mathrm{~g} / \mathrm{L})$ DMEM with L-glutamine (4 mM) (Gibco, USA), 10\% FBS (Gibco, USA), and 1× antibiotic-antimycotic (Gibco, USA) and were incubated at $37^{\circ} \mathrm{C}, 5 \% \mathrm{CO}_{2}$. Medium was changed every $2-3$ days. After reaching $80-90 \%$ confluency, the cells were subcultured and expanded to passages 2, 3, and 4 to be used for further assays.

\section{Characterization of ADSCs Multipotency assay}

ADSCs passage 2 were cultured in a 24-well plate $\left(1 \times 10^{4}\right.$ cells/well) in basic growth medium. Medium was changed every 2-3 days. After cells reached $80 \%$ confluency, medium was replaced with StemPro differentiation kit (Gibco, USA) for chondrogenic, osteogenic, and adipogenic for 7 days. The cells were fixed in 10\% formalin and then stained with Oil red $\mathrm{O}$, alcian blue, and alizarin red for adipocytes, chondrocytes, and osteocytes, respectively. Cell differentiation was observed using an inverted microscope (OPTICA microscope, Italy). 


\section{Surface marker protein analysis}

Cell surface marker analysis was performed by flow cytometry (Miltenyi Biotec) to confirm the stem cell characteristics of ADSCs. The cell surface markers used were CD73 allophycocyanin (APC), CD90 fluorescein isothiocyanate (FITC), and CD105 peridinin-chlorophyll-protein (PerCP) Cy5.5 as positive MSCs markers, and lineage negative marker-PE including CD34, CD45, CD11b, CD19, and human leukocyte antigen (HLA)-DR (Becton Dickinson) as positive haematopoietic cells markers. The cells $\left(1 \times 10^{5}\right.$, passage 3$)$ were stained with fluorescencelabelled probes specific to cell surface molecule. Data were obtained from 10,000 events per analysis.

\section{Characterization of PRP}

PRP which was liquid form was obtained from Indonesian Red Cross Society (IFRC), Jl. Kramat Raya, No. 47, Central Jakarta, DKI Jakarta (10450). The time between blood drawing, PRP processing, activation, and delivery have been conducted in a day. The PRP was stored at $-21^{\circ} \mathrm{C}$ without light exposure.

\section{Platelet, erythrocyte, and leucocyte measurement}

About $200 \mu \mathrm{l}$ of PRP was aliquot into $1.5-\mathrm{ml}$ sterile microtubes. The sample was analysed using the Sysmex KX-21 automated haematology analyser, which was calibrated before analysing the blood cells and platelet counts in PRP. Platelet measurement was done twice for each PRP batch.

\section{Level of TGF- $\beta 1$}

The protein level of TGF- $\beta 1$ was determined using the enzyme-linked immunosorbent assay (ELISA) following the protocol provided by R\&D systems, USA. According to manufacturer's instruction, the standard stock solution of TGF- $\beta 1$ was serially diluted to form standards of 2000 $\mathrm{pg} / \mathrm{ml}, 1000 \mathrm{pg} / \mathrm{ml}, 500 \mathrm{pg} / \mathrm{ml}, 250 \mathrm{pg} / \mathrm{ml}, 125 \mathrm{pg} / \mathrm{ml}, 62.5$ $\mathrm{pg} / \mathrm{ml}$, and $31.3 \mathrm{pg} / \mathrm{ml}$. Next, $50 \mu \mathrm{l}$ diluent solution RD173 was added to each 96 well-plate. The standard samples and solutions were then added to the 96 well-plate each and incubated for $2 \mathrm{~h}$ at $20-25^{\circ} \mathrm{C}$. In the next step, the wells were flushed with $400 \mu \mathrm{l}$ wash buffer, and $100 \mu \mathrm{l}$ TGF- $\beta 1$ antibody solution was added and incubated at room temperature for $30 \mathrm{~min}$ in the dark. In the last step, $100 \mu \mathrm{l}$ stop solution was added. The TGF- $\beta 1$ concentration value was determined as absorbance using a microplate reader (iMark BioRad) at a wavelength of $450 \mathrm{~nm}$.

\section{Total protein of PRP}

The total protein content of PRP was analysed using the Pierce $^{\text {tx }}$ Bicinchoninic acid (BCA) Protein Assay Kit (Thermo Scientific, USA). According to manufacturer's instruction, the total protein measurement was initiated by preparing standard concentrations of $0-2000 \mu \mathrm{g} / \mathrm{ml}$ albumin (Thermo Scientific, USA). The samples, standards, and $50 \mu \mathrm{l}$ control (distilled water) were then dissolved in $1 \mathrm{ml}$ working reagent. Next, the samples, standards, and control were incubated at $37^{\circ} \mathrm{C}$ for $30 \mathrm{~min}$, followed by a room temperature $\left(\sim 20-25^{\circ} \mathrm{C}\right)$ incubation for $5 \mathrm{~min}$. The result obtained was then read at a wavelength of $562 \mathrm{~nm}$ using a Nanodrop One, Thermo Fisher.

\section{Cells proliferation assay}

ADSCs at passage $4\left(1 \times 10^{5}\right)$ were cultured on silk fibroin scaffolds (ADSC-SS) in various medium (StemPro chondrogenesis differentiation kit as positive control, 10\% FBS in DMEM as negative control, and 10\% PRP in DMEM). Cell growth was analysed to determine the biocompatibility of silk fibroin scaffold with ADSCs. The culture medium in the treatment and control groups of the scaffold was removed and the cells were washed with Hank's balanced salt solution (HBSS) (Gibco, USA). On days 1, 3, 5, 7, 14, and 21, $100 \mu \mathrm{l}$ DMEM (Gibco, USA) and the reagent of $10 \mu \mathrm{l}$ 3-(4,5-dimethylthiazol-2-yl)-2,5-diphenyltetrazolium bromide (MTT) (Sigma-Aldrich) were added to the cells in 96-well plates and incubated for $4 \mathrm{~h}$. The solution in the wells was then replaced with $100 \mu$ dimethyl sulfoxide (DMSO) and incubated for $10 \mathrm{~min}$ in a $\mathrm{CO}_{2}$ incubator (Thermo Fisher Scientific). The absorbance of the solution in the wells was determined using a microplate reader (iMark BioRad) at a wavelength of $595 \mathrm{~nm}$.

\section{Differentiation assays}

ADSCs at passage $4\left(1 \times 10^{5}\right)$ were cultured on silk fibroin scaffold in various medium (StemPro chondrogenesis differentiation kit as positive control, 10\% FBS in DMEM as negative control and 10\% PRP in DMEM). The cells were analysed on days $1,3,5,7,14$, and 21 for GAG levels and mineralization. The TGF- $\beta$ level was measured on days 7,14 , and 21 , and the surface protein expression compared to the stem cell monolayer before culture on a silk fibroin scaffold (passage 3) was determined on day 21 .

\section{Secretion of TGF- $\beta 1$}

Each group's medium of ADSC-SS was removed and the cells were washed three times using HBSS followed by cell starvation in DMEM low glucose medium which was incubated at $37^{\circ} \mathrm{C}$ in $5 \% \mathrm{CO}_{2}$ for $24 \mathrm{~h}$. The medium was then aspirated and used for determination of TGF$\beta 1$ levels and the total protein concentration secreted by ADSC-SS using ELISA (R\&D system, USA) and Pierce ${ }^{\text {tw }}$ Bicinchoninic acid (BCA) Protein Assay Kit (Thermo Scientific, USA), respectively, as aforementioned.

\section{Glycosaminoglycans (GAG) analysis}

This test was done to measure the GAG in ADSC-SS indicating chondrogenesis using alcian blue stain. Alcian 
blue is used to stain acidic polysaccharides, such as GAG. The cells were fixed in $4 \%$ paraformaldehyde for $15 \mathrm{~min}$. This $4 \%$ paraformaldehyde was then removed and $1 \%$ alcian blue in $3 \%$ acetic acid was added to the fixed cells for $30 \mathrm{~min}$. Alcian blue was then removed and washed thrice with $3 \%$ acetic acid for $2 \mathrm{~min}$. The deionizing solution was then added and incubated for $2 \mathrm{~min}$. The washed cells were then mixed with $100 \mu \mathrm{l}$ of $1 \%$ sodium dodecyl sulphate (SDS) and mixed in a shaker at $200 \mathrm{rpm}$ for $30 \mathrm{~min}$. The GAG content was determined based on the absorbance value of this solution at a $595 \mathrm{~nm}$ wavelength on a microplate reader (iMark Bio-Rad).

\section{Mineralization}

The purpose of mineralization test is to determine the level of deposited $\mathrm{Ca}^{2+}$ in cells. This test for osteogenesis confirms the differentiation of ADSC-SS in each treatment group. The mineralization test was performed as described previously [17] with modifications. At each analysis, ADSC-SS were fixed in $4 \%$ paraformaldehyde for $15 \mathrm{~min}$, followed by Alizarin Red S staining and washing thrice with HBSS (Gibco, USA). Next, 10\% acetic acid was added to the stained cells. The mineral content was read by absorbance values at $415 \mathrm{~nm}$ wavelength using a microplate reader (iMark Bio-Rad).

\section{Expression of specific stem cell surface protein markers}

This test was performed to determine the consistency of the differentiation direction of ADSC-SS into chondrocytes, which was analysed on day 21. The protocol and analysis of surface marker proteins was performed referring to the BD Stemflow ${ }^{\text {ma }}$ hMSC Analysis Kit (BD Biosciences). The expression of cluster of differentiation (CD) 73, CD90, CD105, and CD34/CD45/CD11b/CD19 stem cell surface marker proteins in $1 \times 10^{5}$ monolayer cultured ADSCs at passage 3 (ADSC-MN-P3) was compared to that in ADSCs cultured on a silk fibroin scaffold at passage 4 (ADSC-SS-P4). The sample was incubated with a stem cell surface protein antibody for $30 \mathrm{~min}$ and then washed with running buffer. The sample was then centrifuged at $1200 \mathrm{rpm}$ for $5 \mathrm{~min}$. The supernatant was removed, the cell pellet was suspended with $100 \mu \mathrm{l}$ running buffer, and analysed by flow cytometry (Miltenyi Biotec). The percentage result of surface marker protein expression in three groups from ADSC-SS-P4 was compared to that in ADSC-MN-P3.

\section{Gene expressions on mRNA level \\ Primer design}

The accession numbers of glyceraldehyde-3-phosphate dehydrogenase (GAPDH), type 2 collagen, aggrecan, and type 1 collagen were from genecards.org. The messenger ribonucleic acid (mRNA) sequence of the genes was downloaded from ncbi.nlm.gov.nih. Primer design was performed on sg.idtdna.com/ with primer parameters including primer length of 20-24 bases, melting temperature, \%GC content of $40-60 \%$, amplicon size of $75-150 \mathrm{bp}$, and the secondary structure (hairpin, self-dimer, or repeat). Primer sequences are described in Table 1.

\section{Reverse transcription-quantitative polymerase chain reaction ( $R T-q P C R)$}

RT-qPCR was performed using a standard protocol from the MIQE (minimum information for publication of quantitative real-time PCR experiments) guide [18]. ADSC-SS in the PRP group and controls $\left(1 \times 10^{5}\right)$ were harvested on days 7,14 , and 21. RNA isolation was performed using SV Total RNA Isolation System (Promega, USA), following the manufacturer's instructions. Synthesis of complementary deoxyribonucleic acid (cDNA) was performed following the manufacturer's protocol for the GoTaq ${ }^{\circ}$ 2-Step RT-qPCR System (Promega, USA). The mRNA expression of GAPDH, type 2 collagen, aggrecan, and type 1 collagen was analysed using SsoAdvanced ${ }^{\text {Tu }}$ Universal SYBR ${ }^{\circ}$ Green Supermix (BioRad, USA), with the following cycle conditions: an initial denaturation step of $95^{\circ} \mathrm{C}$ for $2 \mathrm{~min}$, followed by 40 cycles of denaturation at $95^{\circ} \mathrm{C}$ for $15 \mathrm{~s}$, and annealing at $54.4{ }^{\circ} \mathrm{C}$ for 1 min, and a final extension at $60-95^{\circ} \mathrm{C}$ for $5 \mathrm{~s}$. The result of qPCR was analysed following the $2^{-\Delta \Delta C T}$ method described by Livak and Schmittgen [19].

Table 1 Primer sequences

\begin{tabular}{lllll}
\hline Gene & & Accession number & Base & Base pairs (bp) \\
\hline GAPDH & Forward & NM_001256799.2 & CAAGAGCACAAGAGGAAGAGAG & 22 \\
& Reverse & & CTACATGGCAACTGTGAGGAG & 22 \\
Type 2 collagen & Forward & NM_001844.4 & GAACCCAGAAACAACACAATCC & 22 \\
& Reverse & & CATTCAGTGCAGAGTCCTAGAG & 21 \\
Aggrecan & Forward & NM_001135.3 & CAGAATGGGAACCAGCCTATAC & 22 \\
Type 1 collagen & Reverse & & GCCTTCTGTACTTCCTCTGT & 22 \\
& Forward & NM_000088.3 & AGAGTGGAGCAGTGGTACTA & 21 \\
\hline
\end{tabular}




\section{Localization and abundance of type 2 collagen using immunocytochemistry}

Immunocytochemistry protocol was followed as described previously [20] with modification. The three groups of ADSC-SS PRP and control groups on days 7, 14, and 21 were fixed with serial methanol concentrations in DMEM (Gibco, USA) $(50 \%, 70 \%, 80 \%, 90 \%)$ for $5 \mathrm{~min}$ each at $20^{\circ} \mathrm{C}$. ADSC-SS was then fixed with $100 \%$ methanol for $20 \mathrm{~min}$ at $-20^{\circ} \mathrm{C}$. The fixation was continued with $50 \%$ methanol-phosphate-buffered saline (PBS) for $5 \mathrm{~min}$ at $-20^{\circ} \mathrm{C}$ temperature, followed by washing thrice with HBSS (Gibco, USA) at room temperature. The fixed ADSC-SS was then stabilized with Tween 20 in PBS (PBST, $0,05 \%$ Tween concentrate) and blocked with 3\% bovine serum albumin (BSA) in PBST. The blocking for ADSC-SS was followed by overnight incubation with the primary antibody against type 2 collagen (Rabbit Anti-Collagen II Antibody (Abcam, UK) (the antibody concentration was 1: 200)) in a water bath. The next step was washing the sample thrice using PBS/de-ion. The washed ADSC-SS was then incubated with secondary goat anti-rabbit IgG H\&L Alexa Flour 488 antibody (Abcam, UK) (the antibody concentration was 1:200), followed by three washes using PBS/ de-ion. The washed ADSC-SS was then incubated in PBSde-ion containing 4',6-diamidino-2-phenylindole (DAPI) at $5 \mu \mathrm{g} / \mathrm{ml}$. Images were acquired and observed randomly using the Olympus confocal microscope type Fv1200 with Fluoview software at 3 points by sectioning at $\sim 40 \mu \mathrm{m}$ of 20 slices for $1 \mathrm{~mm}$ thickness. The percentage value from the average of type 2 collagen intensity per three comprehensive areas in the image was determined using Image software (National Institutes of Health, USA).

\section{Statistical analysis}

The data from each parameter was presented as average \pm standard deviation (SD) in the tables and charts. Statistical analysis began with normality and homogeneity testing. The differences were analysed $(p<0.05)$ using a parametric statistical test analysis of variance (ANOVA) and it was applied to the proliferation and differentiation test of ADSC-SS, the cell surface marker protein levels in chondrocyte progenitors, measurement of mRNA expression, and the abundance of type 2 collagen.

\section{Results}

\section{Stromal vascular fraction (SVF)}

The cell number of the SVF including red blood cells in the total count from donors varied with an average of $7.48 \times 10^{7}$ cells $/ 10 \mathrm{~mL}$ adipose tissue and the average of cell viability cell was $99.80 \%$. The demographic of lipoaspirate donors are shown in Additional file 1: Table S1. The morphology of cells isolated from adipose tissue in this study was fibroblast-like and attached to the bottom of the plastic plate (Fig. 1a). This is a characteristic of
MSCs. However, to confirm and identify the MSCs characteristics of isolated cells from adipose tissue, multipotency and cell surface marker expression was analysed.

\section{Multipotency and cell-surface marker expression}

Cells isolated from adipose tissue were differentiated into adipocytes, chondrocytes, and osteocytes in specific commercial induction medium (Fig. 1b-d). Cells that differentiated into adipocytes showed accumulation of lipid droplets in the cells (Fig. 1b). Calcium deposits in osteogenic cells isolated from adipose tissue were detected through alizarin red staining (Fig. 1c). Chondrogenic differentiation was identified by micromass formation that showed blue colour upon alcian blue staining (Fig. 1d).

We also observed that these cells expressed CD73, CD90, and CD105 proteins on their surface. In Fig. 1e, the $X$ axis shows the fluorescent intensity whereas the $Y$ axis shows the number of cells. The red and blue peaks of the histogram represent isotypes and stained cells, respectively. The percentage of positive surface protein expression in a population that is quantified by overlaying with the isotype was more than $95 \%$ for CD73, CD90, and CD105 and less than 2\% for CD34/CD45/CD11b/ CD19 (Fig. 1E). These results indicate that cells isolated from adipose tissue meet the criteria for adipose-derived stem cells (ADSCs) according to the International Society for Cellular Therapy (ISCT) and are hereafter referred to as ADSCs [21]. In addition, the minimum information for studies evaluating biologics in orthopaedics (MIBO) checklist for mesenchymal stem cells is shown in Additional file 1: Table S2.

Platelet number, TGF- $\beta 1$ level, and total protein of PRP The platelet number in PRP was $630 \times 10^{3} / \mu \mathrm{l}$, the TGF- $\beta 1$ level was $22 \mathrm{ng} / \mathrm{ml}$, and the total protein was $4861 \mu \mathrm{g} / \mathrm{ml}$ (Table 2). Proliferation of ADSCs in PRP supplemented medium was investigated in this study. FBS-supplemented and commercially available chondrogenic medium was used for comparison. The MIBO checklist of platelet-rich plasma is shown in Additional file 1: Table S3.

\section{Growth curve of ADSC-SS}

ADSC-SS cultured in various medium for 21 days showed an increase in proliferation from day 1 to day 21 . The results showed that the proliferation of ADSCSS cultured in PRP-supplemented medium showed a higher proliferation rate than those in FBSsupplemented and chondrogenic medium until day 21 . The proliferation rate in the ADSC-SS PRP group was significantly higher $(p<0.05)$ compared to the controls on day 21 (Fig. 2). These results indicated that PRP could increase ADSC growth compared to that in FBSsupplemented or commercial chondrogenic medium (StemPro). 

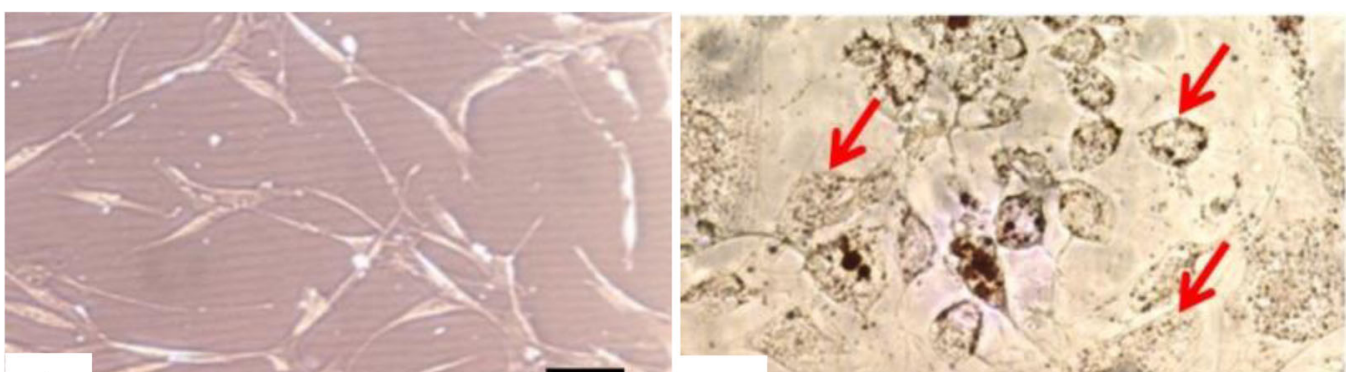

A
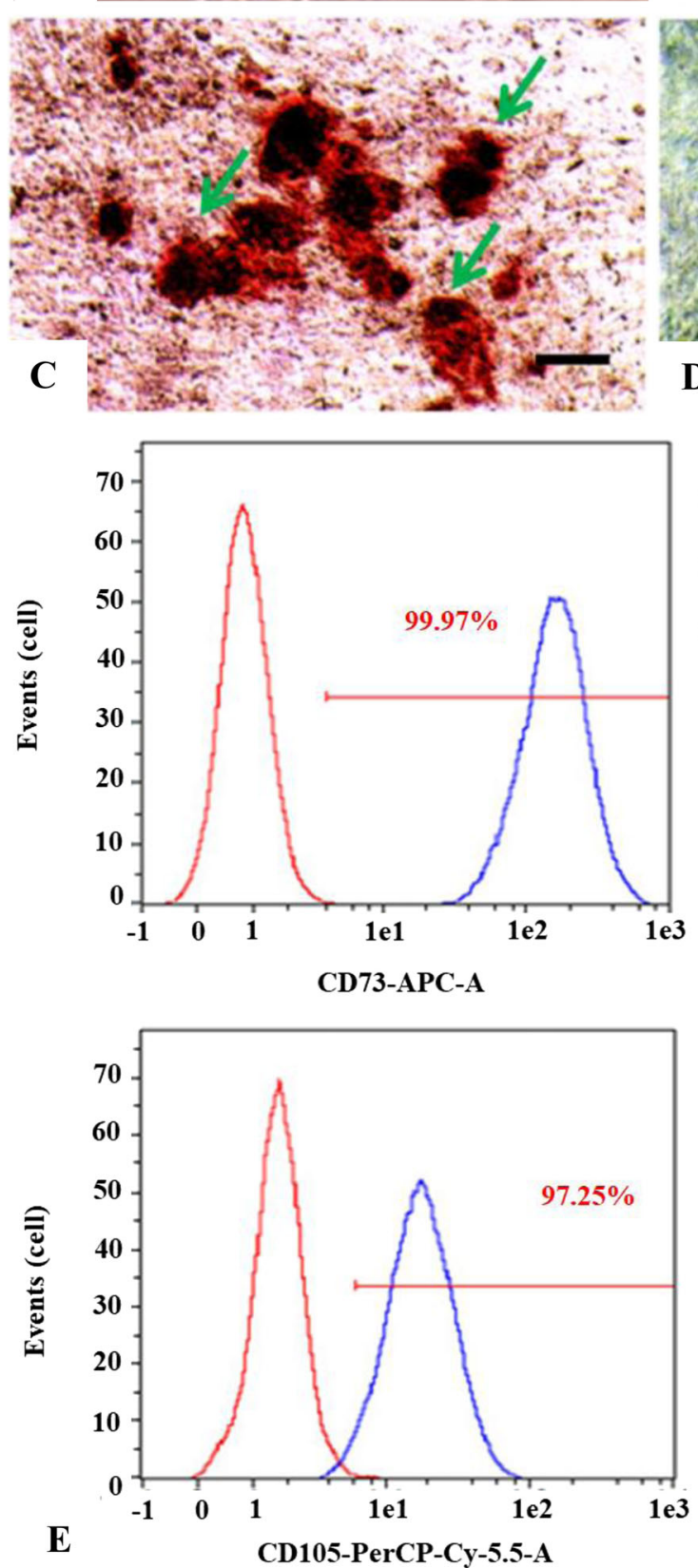

B
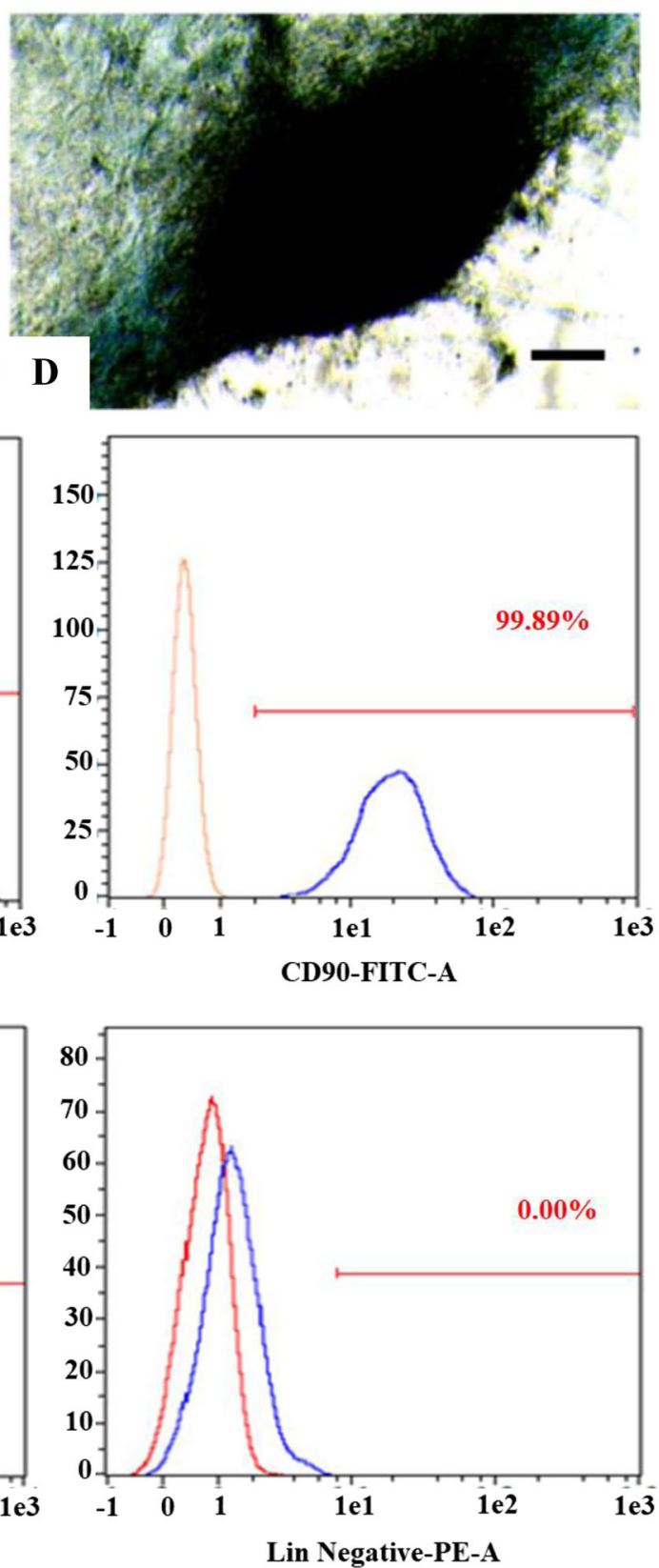

Fig. 1 (See legend on next page.) 
(See figure on previous page.)

Fig. 1 Isolated cells from adipose tissue at passage 1 day 3 showed fibroblast-like morphology (a); multipotency of cells at passage 2 isolated from adipose tissue: differentiation into adipocytes characterized by lipid droplets (red arrows) using Oil Red O staining (b); osteocytes characterized by calcium deposits (green arrow) using alizarin red staining (c); chondrocytes formed micromass-like structures (d) using alcian blue staining (black bar = $100 \mu \mathrm{m}$ ) Optilab Microscope, Nikon; Cells at passage 3 expresses CD73 (99.97\%), CD90 (99.89\%), CD105 (97.25\%) and CD45/CD34/CD1 1b/CD19/HLA-DR less than 2\%. Blue peak histogram indicates Fig 2. Proliferation of ADSCs cultured on silk fibroin scaffold with $500 \mu \mathrm{m}$ pore size (ADSC-SS); $Y$ axis is the proliferation rate of ADSC-SS, $X$ axis indicates the observation day. The proliferation rate of ADSC-SS on various media is gradually increased. On day 21, the proliferation rate of ADSC-SS PRP group is significantly higher than negative and positive controls, respectively $\left({ }^{*} p<0.05\right.$ indicates statistical significance). Sample and red peak histogram indicates isotype control (e)

\section{TGF- $\beta$ level secreted by ADSC-SS}

The concentration of TGF- $\beta 1$ secreted by ADSC-SS during culture was measured at days 7,14 , and 21. To calculate the TGF- $\beta 1$ secreted by ADSC-SS only apart from TGF- $\beta 1$ in the PRP, the medium of ADSC-SS was removed and the cells were washed three times using HBSS followed by cells starvation in DMEM low glucose medium which was incubated at $37^{\circ} \mathrm{C}$ in $5 \% \mathrm{CO}_{2}$ for $24 \mathrm{~h}$. The results showed that secretion of TGF- $\beta 1(\mathrm{pg} / \mathrm{ml})$ and total protein $(\mu \mathrm{g} / \mathrm{ml})$ in ADSC-SS was significantly higher in PRPsupplemented medium than in FBS-supplemented and chondrogenic medium $(p<0.05)$ (Fig. 3a, b). We also observed a significant increase in the total protein content after 14 and 21 days of culture in PRPsupplemented and FBS supplemented groups, compared to the chondrogenic medium group $(p<0.05)$ (Fig. $3 b)$. The TGF- $\beta 1$ level per total protein $(\mathrm{pg} / \mathrm{mg})$ in the ADSC-SS PRP group was significantly higher compared to that in the control groups $(p<0.05)$ (Fig. 3c). The results indicate that PRP supplementation induces increased protein secretion by ADSC-SS including TGF- $\beta 1$, compared to that by FBS and chondrogenic medium.

\section{GAG level of ADSC-SS}

The GAG level of ADSC-SS in PRP and positive control groups was gradually increased whereas the GAG level in the negative control group was relatively stable until 21 days of observation. The level of GAG on day 21 was significantly higher in the PRP and positive control groups compared to that in the negative control $(p<0.05)$ (Fig. 3d).

Table 2 The platelet number, TGF- $\beta 1$ protein level, and total protein concentrations of PRP

\begin{tabular}{llll}
\hline Measurement & \multicolumn{2}{l}{ Batch } & Average \pm SD \\
\cline { 2 - 3 } & 1 & 2 & \\
\hline Leucocytes $\left(\times 10^{3} / \mu \mathrm{l}\right)$ & 0.20 & 0.40 & $0.30 \pm 0.14$ \\
Erythrocytes $\left(\times 10^{3} / \mu \mathrm{l}\right)$ & 0.01 & 0.03 & $0.02 \pm 0.14$ \\
Thrombocytes $\left(\times 10^{3} / \mu \mathrm{l}\right)$ & 275 & 985 & $630 \pm 502$ \\
TGF- $\beta 1$ level $(\mathrm{pg} / \mathrm{ml})$ & 12,451 & 32,834 & $22,642 \pm 14,413$ \\
Protein total $(\mu \mathrm{g} / \mathrm{ml})$ & 3980 & 5742 & $4861 \pm 1246$ \\
\hline
\end{tabular}

These results indicate that ADSC-SS in the PRP and positive control group were undergoing chondrogenesis.

\section{Mineralization level of ADSC-SS}

Mineralization of ADSC-SS cultured in all tested medium were stable at low concentration. The third group of ADSC-SS showed stability until day 7 followed by an increase on day 14 and a decrease on day 21 (Fig. 3e). The low level of mineralization in this study suggested that cells did not lead to osteogenic differentiation.

\section{Surface protein marker expression in chondrocyte progenitors}

To evaluate the change in mesenchymal stem cell (MSC) surface marker expression upon chondrogenesis, the surface markers on ADSCs were measured on day 21. The results showed alteration in CD73, CD90, and CD105 expression on all ADSC-SS compared to that in monolayer ADSCs cultured on polypropylene. These data indicate that the silk fibroin scaffold supported the cell differentiation.

The results confirmed that passage 3 (P3) ADSCs in a monolayer substrate (ADSC-MN) culture grown in negative control medium expressed higher CD73 levels compared to ADSC-SS P4 cultured in PRP or control medium and significantly higher levels compared to ADSC-SS P4 cultured in PRP and positive control medium $(p<0.04)$. CD90 and CD105 expression on ADSC-MN P3 was significantly higher than that on ADSC-SS P4 cultured in PRP or control medium $(p<0.05)$. The negative marker protein (CD34/CD45/CD11b/CD19) expression of ADSCSS P4 was stable at low levels (less than 2\%) compared to that in ADSC-MN P3 (Fig. 3f).

mRNA expression of type 2 collagen, aggrecan, and type 1 collagen

The mRNA expression of type 2 collagen in the ADSCSS PRP group was increased dramatically and was significantly different compared to that in the ADSC-SS negative control on days 7 and $21(p<0.05)$. The mRNA expression of type 2 collagen in the ADSC-SS PRP group was higher compared to that in the ADSC-SS positive control group on days 7 and 21 but was significantly 


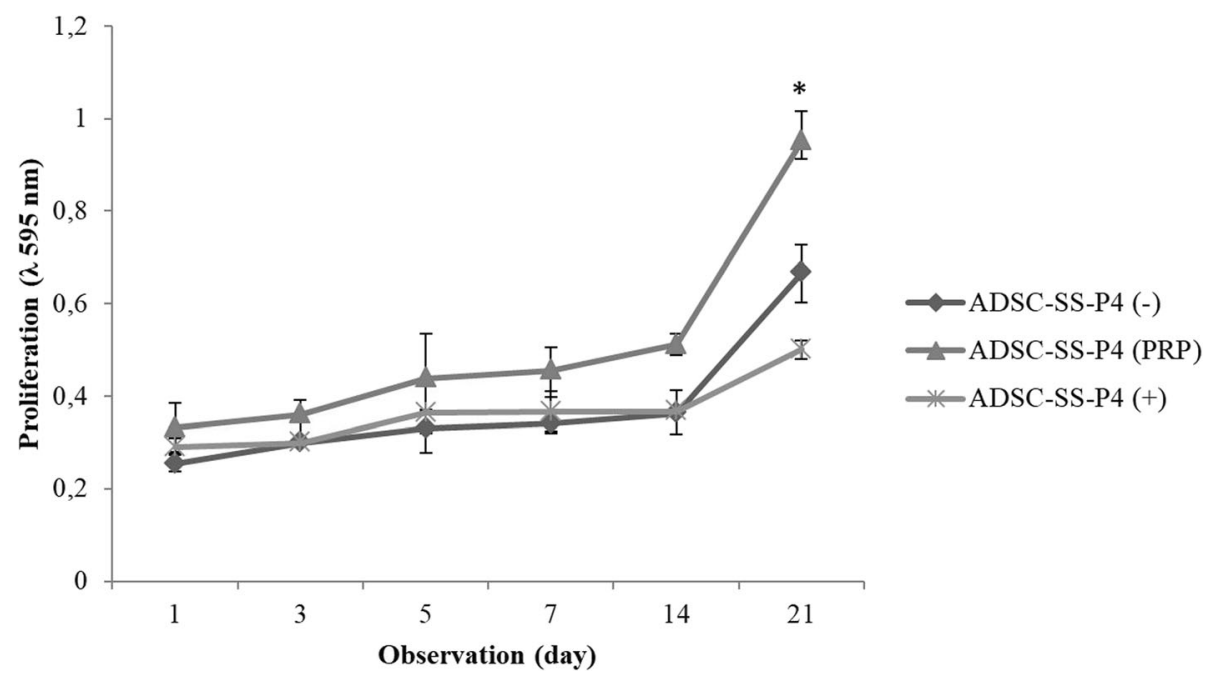

Fig. 2 Proliferation of ADSCS cultured on silk fibroin scaffold with $500 \mu \mathrm{m}$ pore size (ADSC-SS); $Y$ axis is the proliferation rate of ADSC-SS, $X$ axis indicates the observation day. The proliferation rate of ADSC-SS on various media is gradually increased. On day 21 , the proliferation rate of ADSC-SS PRP group is significantly higher than negative and positive controls, respectively ${ }^{*} p<0.05$ indicates statistical significance)

lower than that in the positive controls on day 14 $(p<0.05)$. The mRNA expression of aggrecan in the ADSC-SS PRP group was increased on day 14 and decreased on day 21 . The gene expression of aggrecan on day 14 was also significantly higher compared to that in the negative control $(p<0.05)$ and was significantly lower compared to that in the positive control $(p<0.05)$.

The expression of aggrecan in the ADSC-SS positive control group was significantly higher on day 14 compared to that in the PRP and negative control groups $(p<0.05)$ and was significantly higher on day 21 compared to that in the negative control $(p<0.05)$. The mRNA expression of type 1 collagen in the ADSC-SS PRP group was stable until day 14 and was significantly lower compared to the negative control on day 21 $(p<0.05)$. However, the gene expression of type 1 collagen in the ADSC-SS positive control was dramatically increased and significantly higher compared to that in the ADSC-SS PRP and negative control groups on day 14 $(p<0.05)$ and significantly higher compared to the negative control on day $21(p<0.05)$ (Fig. 4).

\section{Immunocytochemistry of type 2 collagen protein}

Cells cultured on silk fibroin scaffold were found within $\sim 450 \mu \mathrm{m}$ depth using optical sectioning, which indicated that the silk fibroin scaffold supported ADSCs proliferation and infiltration into the scaffold. The silk fibroin scaffold also supported chondrogenic differentiation characterized by the presence of type 2 collagen in cells (Fig. 5). In Fig. 5, ADSC-SS in the negative control group showed almost no detectable presence of type 2 collagen whereas ADSC-SS in the positive control group showed the presence of type 2 collagen outside the cells.
The presence of type 2 collagen in the ADSC-SS in the PRP and positive control groups increased on days 14 and 21 . The presence of type 2 collagen on day 14 in ADSC-SS from the PRP group was observed both inside and outside the cell. On day 21, type 2 collagen in ADSC-SS in the PRP group was highly expressed outside the cells. The presence of type 2 collagen protein in the ADSC-SS positive control group which was observed on days 14 and 21 was outside the cells (Fig. 5).

The percent intensity of type 2 collagen in the treatment groups was very low on day 7 . The intensity percentage of type 2 collagen in ADSC-SS with PRP and in the positive control groups was significantly higher compared to that in the negative control group on days 14 and 21 . On day $21(p=0.0003)$, the intensity percentage of type 2 collagen in ADSC-SS and the positive control groups was $12.26 \%$ and $14.27 \%$, respectively (Fig. 6).

Percentage of type 2 collagen protein intensity in ADSC-SS PRP and positive control groups on day 21 was significantly increased compared to that on day 7 and $14 \quad(p<0.04)$. The presence of an extracellular matrix $(E C M)$ of type 2 collagen in this study indicates the chondrogenesis in the ADSC-SS PRP and positive control groups on days 14 and 21 .

Based on this study, the mechanism underlying the increased chondrogenesis in the ADSC-SS PRP group was suggested as follows (Fig. 7). TGF- $\beta 1$ protein is recruited by the cells to induce the expression of chondrogenesis-related proteins. The ADSC-SS PRP group showed an increase in the proliferation rate, GAG levels, and expression of type 2 collagen at the mRNA and protein levels on days 14 and 21 , whereas it showed an increase in the expression level of aggrecan at the mRNA level on day 14 and a decrease in its 

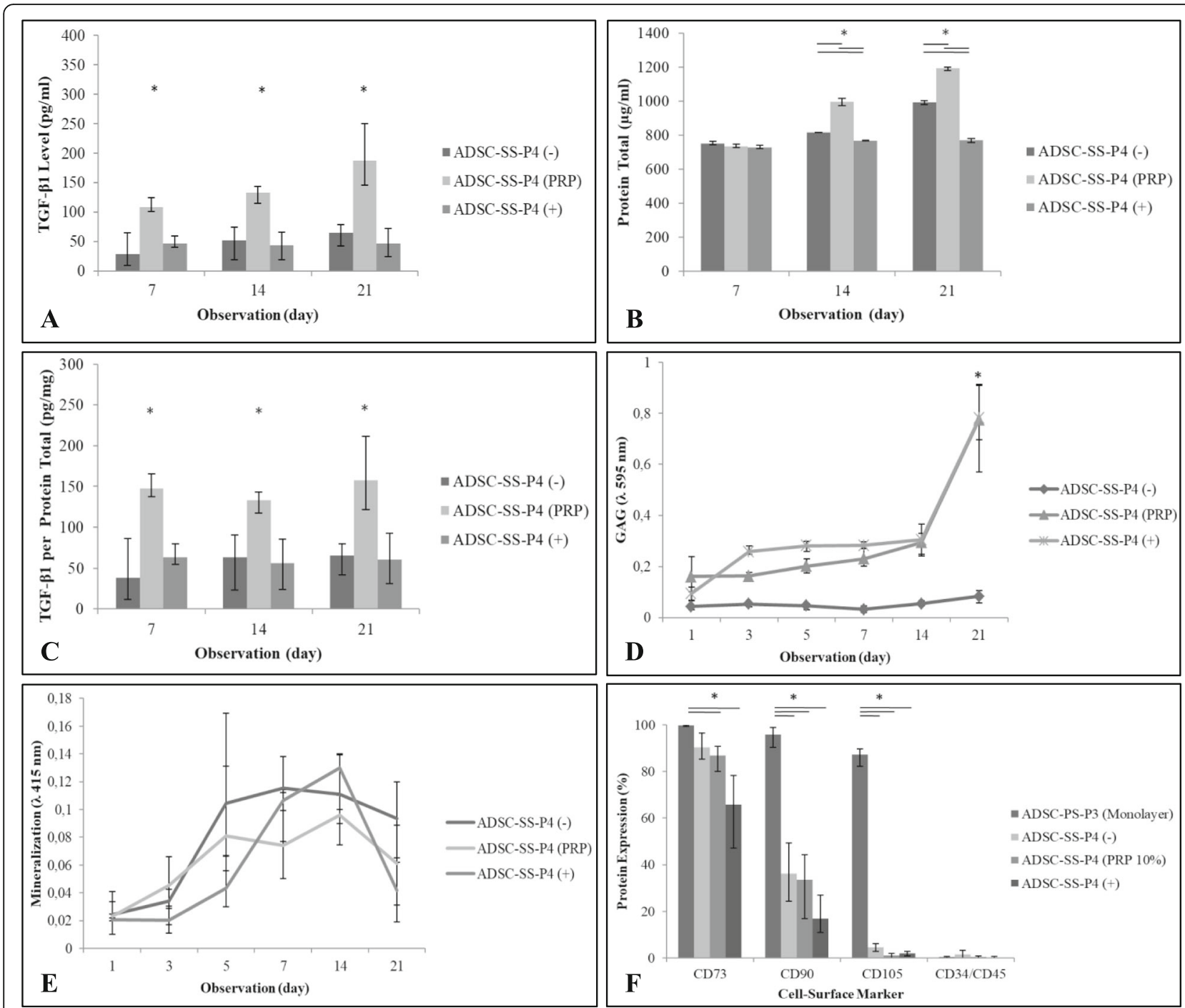

Fig. 3 Confirmation of ADSCs differentiation. TGF- $\beta 1$ level $(\mathrm{pg} / \mathrm{ml})(\mathbf{a})$, total protein $(\mu \mathrm{g} / \mathrm{ml})(\mathbf{b})$, TGF- $\beta 1$ levels per total protein (pg/mg) (c) secreted by ADSC-SS after starvation for $24 \mathrm{~h}$ on day 7, 14 and 21 of observation. ADSC-SS in PRP and negative control are gradually increased on day 14 and 21 while ADSC-SS in positive control is stable. The TGF- $\beta 1$ level which secreted by ADSC-SS PRP group shows significantly different to both of controls on day 7, 14, and 21 of observation; GAG level is dramatically increased in the ADSC-SS PRP and positive control groups and significantly different compared to that in the ADSC-SS negative control on day 21 (d); mineralization of ADSC-SS in PRP and control groups are stable in low level for 21 day of observation (e); and cell-surface protein expression in ADSC-SS group on day 21 passage 4 compared to that in monolayer ADSCs passage 3, both of ADSC-SS in PRP and positive control are significantly decreased their specific stem cell surfaceprotein markers (CD73, CD90, CD105) compared to that the ADSC-SS-PS (monolayer) (f). ( ${ }^{*} p<0.05$ indicates statistical significance)

expression level on day 21. Furthermore, the expression of type 1 collagen was detected at a low level on days 7 and 14 and was significantly decreased on day 21 .

\section{Discussion}

ADSCs are characterized as fibroblast-like, multipotent (differentiate into several types of cells, like adipocytes, chondrocytes, osteocytes) cells that express CD73, CD90, and CD105 (>95\%) and no CD34, CD45, CD11b, and CD19 $(<2 \%)[22,23]$. ADSC differentiation into adipocytes are marked by lipid droplets, which are markers of adipogenesis [24]. Furthermore, chondrogenesis and osteogenesis of ADSCs were determined through micromass formation [9] and the accumulation of calcium deposits [25], respectively. These results indicate that cells isolated from fat tissue were ADSCs. Another component that was characterized was PRP. Studies have reported that $1 \times 10^{9}$ platelets/ $\mathrm{ml}$ in PRP can induce chondrogenesis as well as osteogenesis. The one thing that should be noted for chondrogenesis using PRP is the TGF- $\beta 1$ level [26-28]. In addition, previously studies reported that the TGF- $\beta 1$ level which is $10-40$ $\mathrm{ng} / \mathrm{ml}$ in ranges supports chondrogenesis ADSCs [29-31]. 

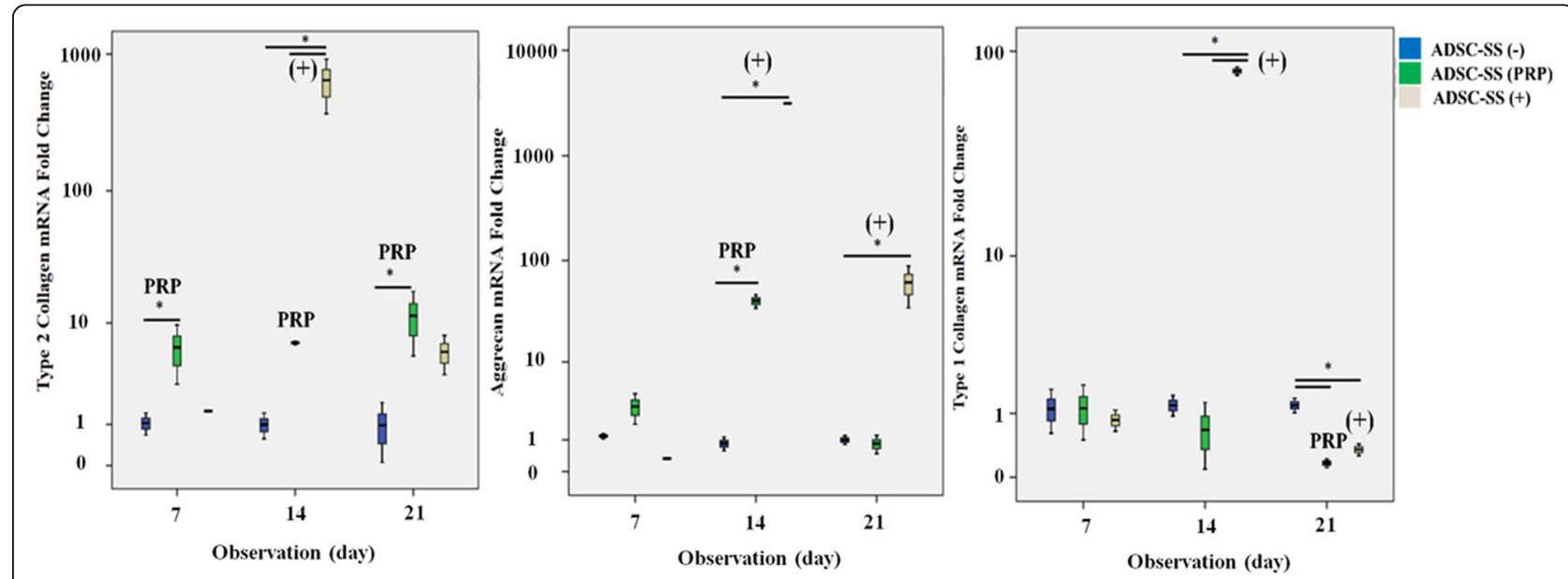

Fig. 4 Relative mRNA expression of type 2 collagen (a), aggrecan (b), and type 1 collagen (c) in ADSC-SS PRP and control groups on day 7, 14, and 21. On day 21, ADSC-SS with PRP supplementation induced highest level of type 2 collagen compared to positive and negative controls and expressed low level of aggrecan or type 1 collagen. ( ${ }^{*} p<0.05$ indicates statistical significance)

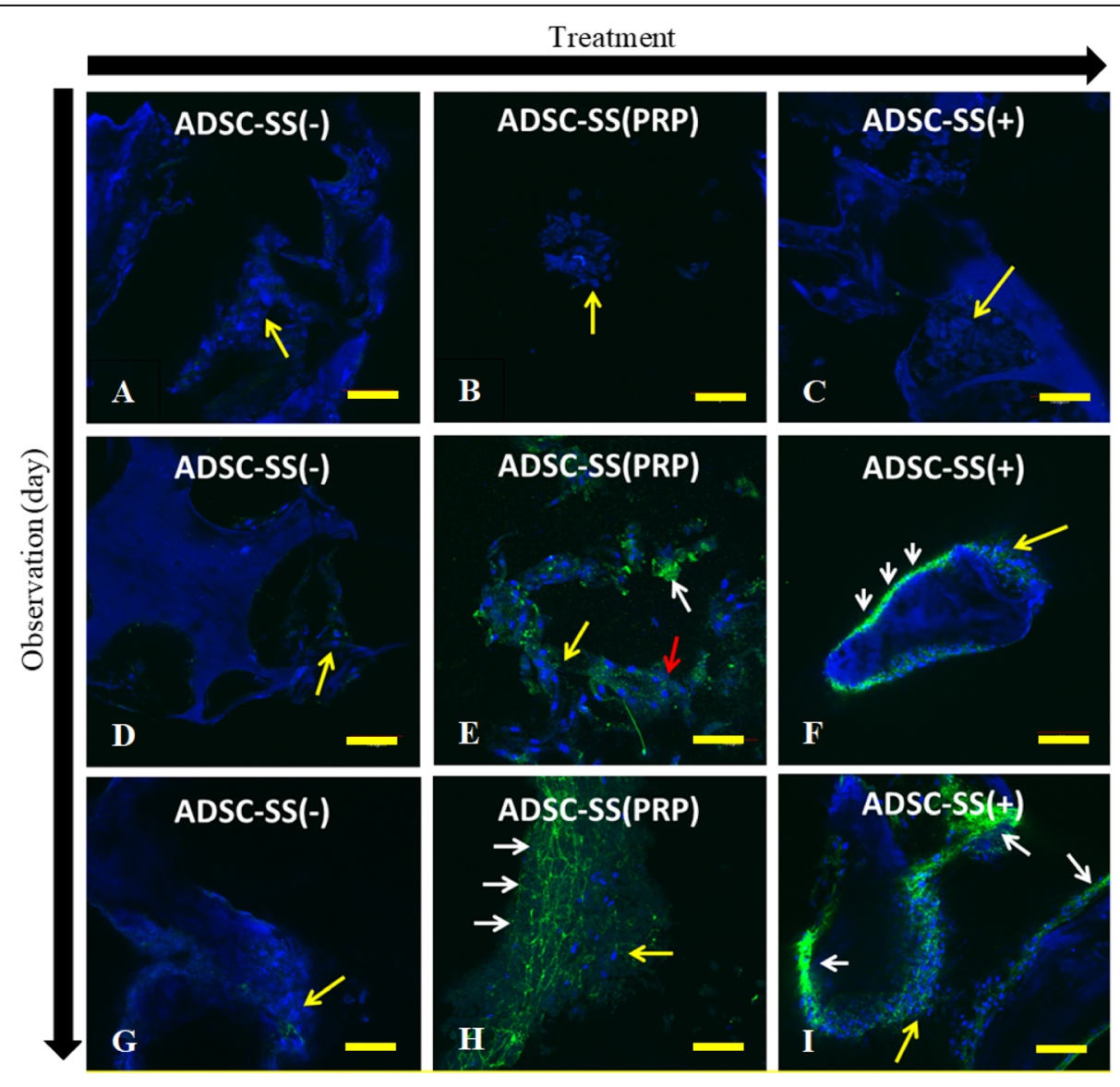

Fig. 5 Immunohistochemistry for type 2 collagen (green) in ADSC-SS cultured on medium with 10\% FBS (negative control), 10\% PRP, and StemPro (positive control) on days $7(\mathbf{a}-\mathbf{c}), 14(\mathbf{d}-\mathbf{f})$, and $21(\mathbf{g}-\mathbf{i})$; cell nucleus (oval shape) in blue colour (DAPI) is shown by yellow arrows; the silk fibroin scaffold was also stained blue. Type 2 collagen in the cytoplasm is shown by a red arrow; type 2 collagen was outside the cells is shown by white arrows. Cells were observed at $\times 200$ magnification on an Olympus Fv1200 confocal microscope (yellow scale bar $=100 \mu \mathrm{m}$ ) 


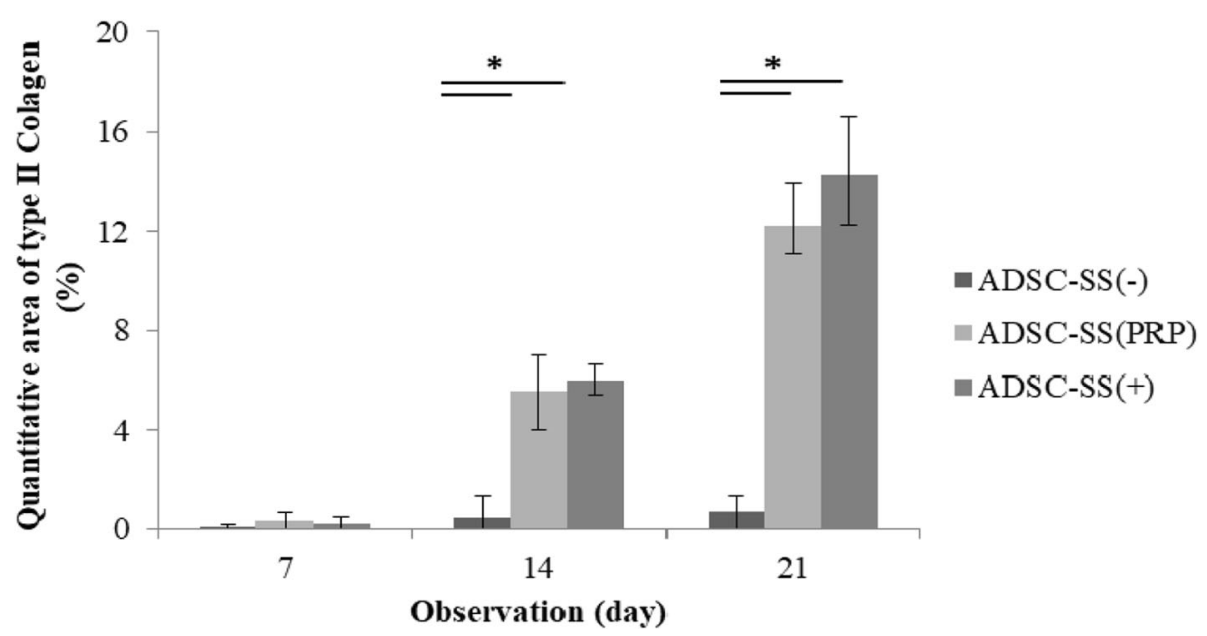

Fig. 6 Percentage of type 2 collagen intensity in ADSC-SS PRP and control groups on days 7, 14, and 21. ADSC-SS PRP and positive control expressed significantly higher type 2 collagen percentage on day 14 and 21 compared to negative control group $\left({ }^{*} p<0.05\right.$ indicates statistical significance)

In this study, the average of platelet number was below $10^{9}$ platelet $/ \mathrm{ml}$ but the TGF- $\beta 1$ levels of PRP were in the range of the optimal concentration to induce chondrogenesis. Our preliminary study showed that 10\% PRP induced chondrogenesis in human ADSCs as determined by alcian blue staining [32]. Furthermore, ADSCs cultured on silk fibroin scaffolds (ADSC-SS) in 10\% PRP medium showed highest proliferation rates compared to the controls, suggesting that PRP contains plenty of mitogenic factors. Mitogen factors such as fibroblast growth factor (FGF), platelet-derived growth factor (PDGF), TGF- $\beta$, and macrophage inhibitory factor (MIF) play a role in the growth of ADSCs are present in PRP [33-36]. In this study, the TGF- $\beta 1$ level was measured, but the measurement for other factors was not performed. However, the results of the total protein assay indicate that the total protein level is approximately $5.5 \times 10^{6}$ times higher than the TGF- $\beta 1$ level.

The high content of mitogen factors in PRP resulted in ADSC aggregation earlier than that in both controls. Cell aggregation is the first stage where cartilage-specific protein markers are produced [37]. ADSC-SS in 10\% PRP medium also secreted higher levels of TGF- $\beta 1$ compared to the controls suggesting that cells were undergoing the chondrogenesis process. Moreover, increasing total protein levels in ADSC-SS PRP and in the negative control group on days 14 and 21 probably resulted due to secretion of other proteins that act as mitogen factors. However, increased TGF- $\beta 1$ and total protein levels were not found in the ADSC-SS positive control group until

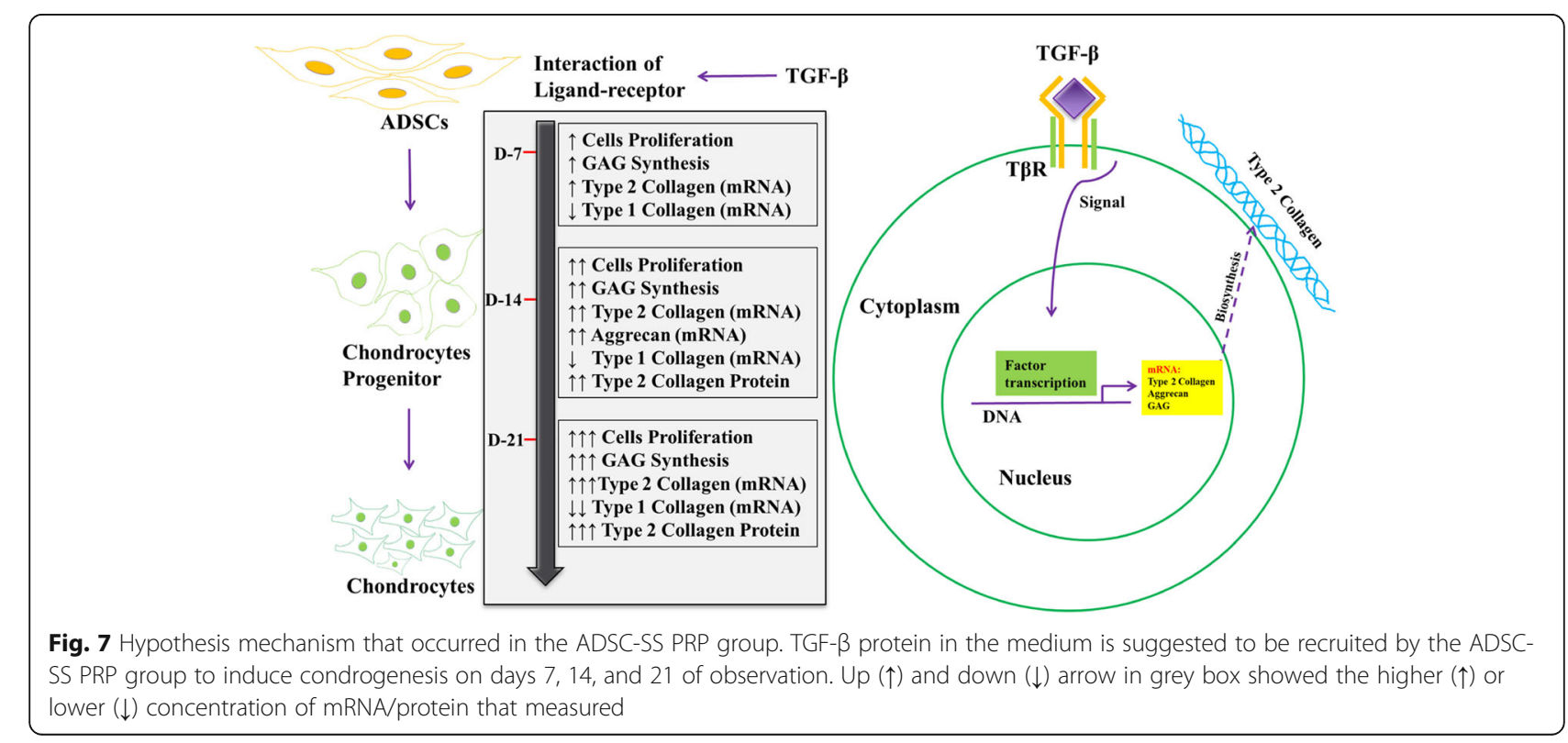


day 21 of observation. This might be caused by the fact that the positive control medium contained an optimal level of TGF- $\beta 1$ for the chondrogenesis process. Therefore, ADSCs were not induced to secrete TGF- $\beta 1$. Furthermore, the GAG level in the ADSC-SS PRP and positive groups was significantly higher $(p>0.05)$ than that in the negative control group on day 21 . The increasing level of GAG is a sign that the chondrogenesis process had occurred $[38,39]$. In this study, ADSC-SS in PRP and the positive control did not differentiate into osteocytes as proven by mineralization analysis.

After 21 days, only ADSC-SS in the PRP and positive control groups showed reduced CD73, CD90, and CD105 expression, which might indicate that the cells were in the differentiation process. Reduction in cellsurface markers of MSCs during differentiation into chondrocytes has also been reported in other studies. A similar study inducing chondrogenesis in bone marrowderived mesenchymal stem cells (BMSCs) cultured on alginate scaffolds showed a significant decrease in CD90 and CD105 [40]. Another study proved that chondrogenesis in MSCs decreased the expression of CD73, CD90, and CD105 [41, 42]. However, the negative control group also showed a significant decrease in CD90 and CD105 expression, which suggested early differentiation of ADSCs into other specific progenitors. We could not predict the differentiation lineage of ADSC-SS in the negative control group because the differentiation was not supported by chondrogenesis or osteogenesis data. Moreover, decreasing CD90 and CD105 was suggested to be caused by the interaction of the cells with the silk fibroin scaffold. We were unable to elucidate the function of the silk fibroin scaffold in differentiation based on this study. Therefore, further studies related to the advantages of using silk fibroin scaffold for cell differentiation of ADSCs are needed. Gene expression at the mRNA level was assessed to confirm the differentiation process.

The mRNA expression of chondrogenesis marker is induced by several effector proteins initiated by transcription factor genes [43]. In this study, type 2 collagen and aggrecan were used as chondrocyte markers whereas type 1 collagen was an osteocyte marker. Increasing gene expression of type 2 collagen and aggrecan at mRNA level in the ADSC-SS PRP and positive control groups suggested that chondrogenesis had occurred. In this study, type 2 collagen and aggrecan were synthesized by cells through recruitment of TGF- $\beta$ protein in the medium. Gene expression of type 1 collagen showed the lowest level for the PRP group on every observation day whereas type 1 collagen expression in the positive control group was increased on day 14 followed by a significant decrease on day 21, suggesting that chondrogenesis suppressed the synthesis of the osteogenesis marker protein. The chondrocyte ECM composed of type 2 collagen and aggrecan maintain chondrogenesis by suppressing the expression of osteogenesis marker proteins $[44,45]$.

The proliferation, infiltration, and differentiation of ADSCs were also confirmed by immunocytochemistry. Infiltration of ADSCs cultured on silk fibroin/hydroxyapatite scaffolds with $\sim 112 \mu \mathrm{m}$ pore size showed increased growth and ECM secretion of chondrocytes [46]. Other studies using various types of cells and scaffolds including human MSCs, 3 T3 fibroblasts, and MC3T3E1 cells in poly $\varepsilon$-caprolactone (PCL)/gelatin scaffolds, porous poly (L-lactide) (PLLA), and PLLA/polyethylene oxide (PEO) showed that cells could infiltrate $\sim 300, \sim$ 350 , and $\sim 600 \mu \mathrm{m}$ size of pores [47-49]. The results in this study showed that the ADSC-SS PRP and positive control were proliferated, infiltrated, and differentiated into chondrocytes supported by the presence of type 2 collagen. The presence of type 2 collagen in the chondrogenesis of BMSCs cultured on silk fibroin is also reported [50]. Chondrogenesis of BMSCs in poly-lactide-co-glycolide (PLGA) scaffolds showed approximately 35\% of type 2 collagen for the culture duration of 42 days [20]. However, in this study, the percentage of type 2 collagen was up to $\sim 12.26 \%$ in 21 days culture.

When the results of this study are compared to similar studies, the hypothesized mechanism is suggested as follows (Fig. 8): TGF- $\beta$ molecules in the medium of PRP and the positive control as well as those secreted by the cells interact with the TGF- $\beta$ receptor. The TGF- $\beta$ ligand-receptor interaction initiates phosphorylation of the Smad $2 / 3$ effector protein. Smad $2 / 3$ protein will make a complex with Smad 4 and then translocate into the nucleus to express genes regulated by the sry-related HMG box (Sox 9) transcription factor. Sox 9 protein will induce the gene expression of type 2 collagen, aggrecan, and GAG. These genes will then be translated and secreted into the protein ECM of cartilage [15].

In this study, the transcription and translation process of type 2 collagen in the ADSC-SS PRP group suggested that they did not occur at the same time. Type 2 collagen in the ADSC-SS PRP group was only found in the cytoplasm and outside the cells on day 14. This suggested a mechanism of delayed protein synthesis [51]. In the final stage of chondrogenesis, GAG and type 2 collagen form the ECM of chondrocytes. Once the chondrocyte is mature, type 2 collagen interacts with the discoidin receptor 2 domain (DDR2) receptor. This interaction activates extracellular-signal-regulated kinase $1 / 2$ (ERK 1/2) and initiates the activation of runt-related transcription factor 2 (Runx2) transcription factor to regulate the expression of genes related to osteogenesis. The osteogenesis genes include type 1 collagen and Indian hedgehog (Ihh) [43]. 


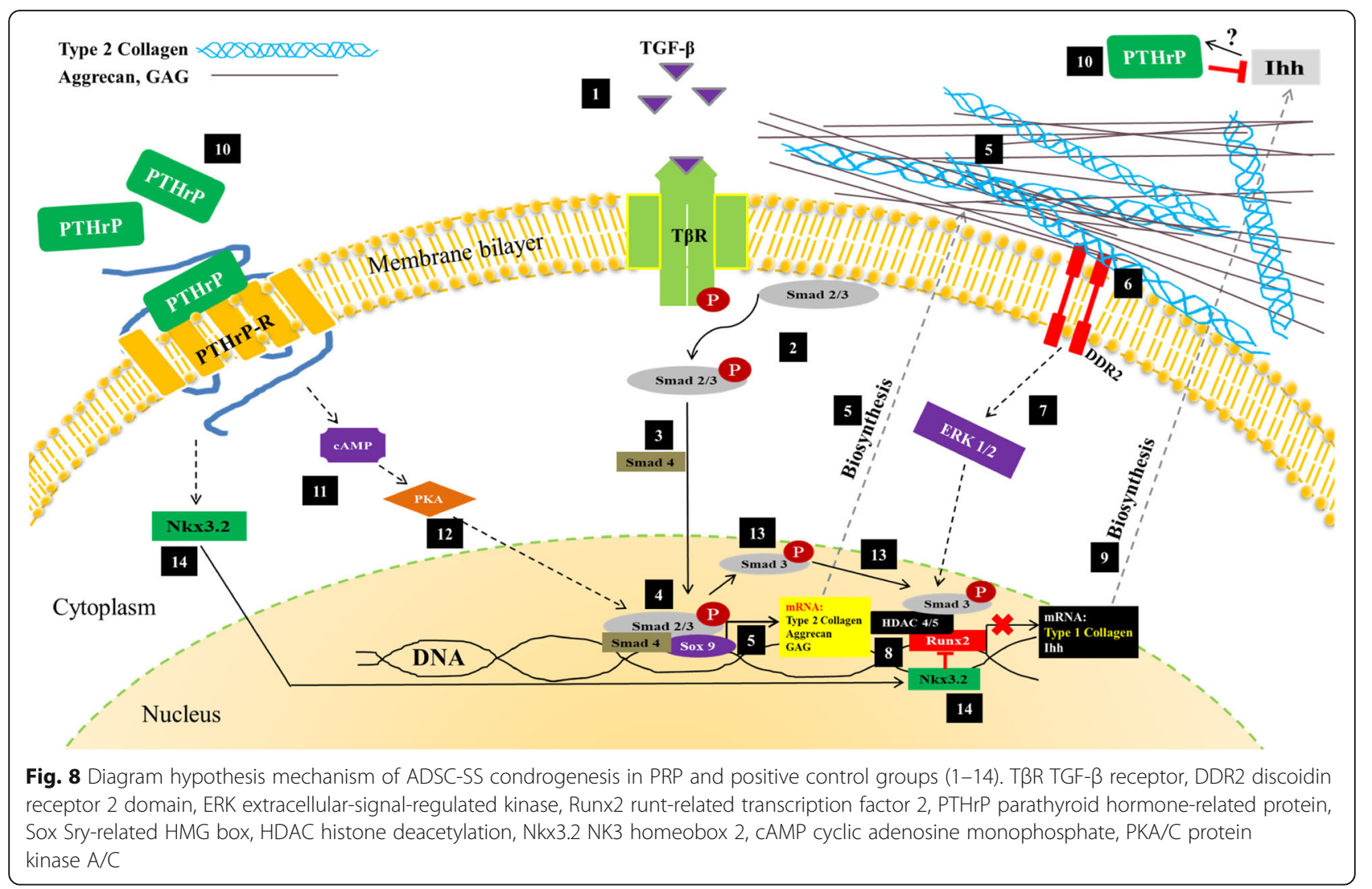

It is suggested that Ihh protein will activate the synthesis of the parathyroid hormone-related protein (PTHrP) protein, but the mechanism underlying this is unclear. PTHrP protein synthesized by the cells will inhibit Ihh indirectly $[43,52]$. Secreted PTHrP protein will interact with the PTHrP receptor, followed by the activation of the cyclic adenosine monophosphate (cAMP) and NK3 homeobox 2 (Nkx3.2) pathways. cAMP will activate protein kinase A (PKA), which will then make a complex with Smad3 protein to de-acetylate Runx2-mediated osteogenesis-related genes. Therefore, the expression of genes related to osteogenesis, such as type 1 collagen, will be suppressed [44, 45, 53, 54]. This mechanism was suggested to explain the increase in type 1 collagen on day 14 followed by the significant decrease in type 1 collagen on day 21 in the ADSC-SS positive control.

\section{Conclusions}

Adipose-derived stem cells cultured on silk fibroin scaffolds with a $500 \mu \mathrm{m}$ pore size (ADSC-SS) in a medium containing $10 \%$ platelet-rich plasma (PRP) were differentiated into chondrocytes, which are characterized by TGF- $\beta 1$ secretion, and increased the expression of glycosaminoglycan as well as type 2 collagen at the mRNA and protein level.

\section{Supplementary information}

Supplementary information accompanies this paper at https://doi.org/10. 1186/s13287-019-1443-2.

Additional file 1: Table S1. Demographics of lipoaspirate donors. Table S2. Minimum Information for Studies Evaluating Biologics in Orthopaedics (MIBO) checklist for mesenchymal stem cells research. The MIBO Checklist template followed by [55]. Table S3. MIBO checklist for platelet-rich plasma research. The MIBO Checklist template followed by $[55,56]$.

\section{Abbreviations}

3D: 3 dimension; ADSC-MN: ADSCs in a monolayer substrate; ADSCs: Adipose-derived stem cells; ADSC-SS: ADSCs cultured on silk fibroin scaffolds; ANOVA: Analysis of variance; APC: Allophycocyanin;

BCA: Bicinchoninic acid; BMSCs: Bone marrow-derived mesenchymal stem cells; BSA: Bovine serum albumin; CAMP: Cyclic adenosine monophosphate; CD: Cluster of differentiation; CDNA: Complementary deoxyribonucleic acid; CS: Chondroitin sulphates; DAPI: 4',6-diamidino-2-phenylindole; DDR2: Discoidin domain receptor 2; DMEM: Dulbecco's modified Eagle's medium; DMSO: Dimethyl sulfoxide; DS: Dermatan sulphates;

ECM: Extracellular matrix; ELISA: Enzyme-linked immunosorbent assay; ERK: Extracellular-signal-regulated kinase; FBS: Foetal bovine serum; FGF: Fibroblast growth factor; FITC: Fluorescein isothiocyanate; GAG: Glycosaminoglycans; GAPDH: Glyceraldehyde 3-phosphate dehydrogenase; HBSS: Hank's balanced salt solution; HDAC: Histone deacetylase; HLA: Human leukocyte antigen; HS: Heparan sulphates; IFRC: Indonesian red cross society; Ihh: Indian hedgehog; ISCT: International Society for Cellular Therapy; KS: Keratan sulphates; MIF: Macrophage inhibitory factor; MIQE: Minimum information for publication of quantitative real-time PCR experiments; mRNA: Messenger ribonucleic acid; MSCs: Mesenchymal stem cells; MTT: 3-(4,5-Dimethylthiazol-2-yl)-2,5-diphenyltetrazolium bromide; Nkx3.2: NK3 homeobox 2; PBS: Phosphate-buffered saline; PBST: Tween 20 in 
PBS; PCL: Poly $\varepsilon$-caprolactone; PDGF: Platelet-derived growth factor; PEO: Porous poly (L-lactide)/polyethylene oxide; PerCP: Peridinin-chlorophyllprotein; PKA/C: Protein kinase A/C; PLGA: Poly-lactide-co-glycolide; PLLA: Porous poly (L-lactide); PRP: Platelet-rich plasma; PTHrP: Parathyroid hormone-related protein; RT-qPCR: Reverse transcriptase-quantitative polymerase chain reaction; Runx2: Runt-related transcription factor 2; SD: Standard deviation; SDS: Sodium dodecyl sulphate; Sox9: Sry-related HMG box 9; SVF: Stromal vascular fraction; TGF- $\beta$ : Transforming growth factor-beta

\section{Acknowledgements}

The authors greatly appreciate the scholarship from the Indonesia Endowment Fund for Education (LPDP). We highly appreciate the Hayandra Peduli Foundation, Hayandra Laboratory, where the research was facilitated and are greatly indebted for the cooperation of the lipoaspirate donors for their lipoaspirate donation.

\section{Authors' contributions}

IRI, KRN, and ABN contributed to the conception and design of the work. IRI, $A B N$, and IRA analysed the data. KRN collected the adipose tissue. IRI, SSH, $|A|$, and TWI contributed to the cell culture works. IRI was responsible for the scaffold fabrication. IRI, IRA, SSH, IAI, and TWI contributed to the data collection and entry. IRI, ABN, and IRA were responsible for the data analysis and interpretation. IRI, IRA, and ABN wrote the manuscript. IRI, ABN, and IRA were responsible for the final approval of manuscript. All authors read and approved the final manuscript.

\section{Funding}

This work was supported by grant from Indonesia Endowment Fund for Education (LPDP) (PRJ-1332 /LPDP.3/2016).

\section{Availability of data and materials}

All relevant data are within the paper.

\section{Ethics approval and consent to participate}

All experimental procedures and manipulations were in compliance and were approved by the Health Research Committee Faculty of Medicine Universitas Padjajaran Bandung (No. 666/UN6.C.10/PN/2017). This experimental study was conducted in ITB-Olympus Bioimaging Centre, Bandung, and HayandraLab Laboratory, Yayasan Hayandra Peduli. The Hayandra Clinic, Yayasan Hayandra Peduli, Jakarta, acquired lipoaspirates from healthy donors with informed consent was provided.

\section{Consent for publication}

Not applicable.

\section{Competing interests}

The authors declare that they have no competing interests.

\section{Author details}

${ }^{1}$ School of Life Sciences and Technology, Institut Teknologi Bandung, Bandung, West Java, Indonesia. ${ }^{2}$ HayandraLab, Yayasan Hayandra Peduli, Jakarta, DKI Jakarta, Indonesia. ${ }^{3}$ Klinik Hayandra, Yayasan Hayandra Peduli, Jakarta, DKI Jakarta, Indonesia. ${ }^{4}$ Biomedic, Universitas Indonesia, Jakarta, DKI Jakarta, Indonesia.

Received: 17 July 2019 Revised: 13 September 2019 Accepted: 3 October 2019 Published online: 04 December 2019

\section{References}

1. Zhang L, He A, Yin Z, Yu Z, Luo X, Liu W, et al. Regeneration of human-earshaped cartilage by co-culturing human microtia chondrocytes with BMSCs. Biomaterials. 2014;35(18):4878-87.

2. Huang SJ, Fu RH, Shyu WC, Liu SP, Jong GP, Chiu YW, et al. Adipose-derived stem cells: isolation, characterization, and differentiation potential. Cell Transplant. 2013:22(4):701-9.

3. Yang $Q$, Teng BH, Wang LN, Li K, Xu C, Ma XL, et al. Silk fibroin/cartilage extracellular matrix scaffolds with sequential delivery of TGF- 33 for chondrogenic differentiation of adipose-derived stem cells. Intern J Nanomed. 2017;12:6721-33.
4. Wu SC, Chen CH, Wang JY, Lin YS, Chang JK, Ho ML. Hyaluronan size alters chondrogenesis of adipose-derived stem cells via the CD44/ERK/SOX-9 pathway. Acta Biomater. 2018;66:224-37.

5. Shahdadfar A, Frønsdal K, Haug T, Reinholt FP, Brinchmann JE. In vitro expansion of human mesenchymal stem cells: choice of serum is a determinant of cell proliferation, differentiation, gene expression, and transcriptome stability. Stem Cells. 2005;23(9):1357-66 Epub 2005 Aug 4

6. Kocaoemer A, Kern S, Klüter H, Bieback K. Human AB serum and thrombin-activated platelet-rich plasma are suitable alternatives to fetal calf serum for the expansion of mesenchymal stem cells from adipose tissue. Stem Cells. 2007;25(5):1270-8.

7. Blande I, Bassaneze V, Lavini-Ramos C, Fae K, Kalil J, Miyakawa A, et al. Adipose tissue mesenchymal stem cell expansion in animal serum-free medium supplemented with autologous human platelet lysate. Transfusion. 2009;49(12):2680-5.

8. Pavlovic V, Ciric M, Jovanovic V, Stojanovic P. Platelet rich plasma: a short overview of certain bioactive components. Open Med (Wars). 2016:11(1):242-7.

9. Pawitan JA, Suryani D, Wulandari D, Damayanti L, Liem IK, Purwoko RY. Prolonged culture in FBS and FBS-substitute containing medium: spontaneous chondrogenic differentiation of adipose tissue derived mesenchymal stem cells. Intern J PharmTech Res. 2014;6(1):224-35.

10. Wang Y, Kim UJ, Blasioli DJ, Kim HJ, Kaplan DL. In vitro cartilage tissue engineering with 3D porous aqueous-derived silk scaffolds and mesenchymal stem cells. Biomaterials. 2005;26(34):7082-94.

11. Meinel L, Hofmann S, Karageorgiou V, Zichner L, Langer R, Kaplan D, VunjakNovakovic G. Engineering cartilage-like tissue using human mesenchymal stem cells and silk protein scaffolds. Biotechnol Bioeng. 2004:88(3):379-91.

12. Hofmann S, Knecht S, Langer R, Kaplan DL, Vunjak-Novakovic G, Merkle HP, Meinel L. Cartilage-like tissue engineering using silk scaffolds and mesenchymal stem cells. Tissue Eng. 2006:12(10):2729-38.

13. Barlian A, Judawisastra H, Alfarafisa NM, Wibowo UA, Rosadi I. Chondrogenic differentiation of adipose-derived mesenchymal stem cells induced by L-ascorbic acid and platelet rich plasma on silk fibroin scaffold. PeerJ. 2018;6:e5809.

14. Soares da Costa D, Reis RL, Pashkuleva I. Sulfation of glycosaminoglycans and its implications in human health and disorders. Annual Annu Rev Biomed Eng. 2017:19:1-26.

15. Studer D, Millan C, Ozturk E, Maniura-Weber K, Zenobi-Wong M. Molecular and biophysical mechanisms regulating hypertrophic differentiation in chondrocytes and mesenchymal stem cells. Eur Cell Mater. 2012;24(24):118-35.

16. Wibowo UA, Judawisastra H, Barlian A, Alfarafisa NM, Moegni KF, Remelia M. Development of salt leached silk fibroin scaffold using direct dissolution techniques for cartilage tissue engineering. Intern J on Adv Sci, Eng and Information Tech. 2019;9(3):810-5.

17. Gregory CA, Gunn WG, Peister A, Prockop DJ. An alizarin red-based assay of mineralization by adherent cells in culture: comparison with cetylpyridinium chloride extraction. Anal Biochem. 2004;329(1):77-84.

18. Bustin SA, Benes V, Garson JA, Hellemans J, Huggett J, Kubista M, et al. The MIQE guidelines: minimum information for publication of quantitative realtime PCR experiments. Clin Chem. 2009:55(4):611-22.

19. Livak KJ, Schmittgen TD. Analysis of relative gene expression data using realtime quantitative PCR and the 2- $\Delta \Delta C T$ method. Methods. 2001;25(4):402-8.

20. Park JS, Yang HN, Woo DG, Jeon SY, Park KH. The promotion of chondrogenesis, osteogenesis, and adipogenesis of human mesenchymal stem cells by multiple growth factors incorporated into nanosphere-coated microspheres. Biomaterials. 2011:32(1):28-38.

21. Bourin P, Bunnell BA, Casteilla L, Dominici M, Katz AJ, March KL, et al. Stromal cells from the adipose tissue-derived stromal vascular fraction and culture expanded adipose tissue-derived stromal/stem cells: a joint statement of the International Federation for Adipose Therapeutics and Science (IFATS) and the International Society for Cellular Therapy (ISCT). Cytotherapy. 2013;15(6):641-8.

22. Zuk PA, Zhu M, Ashjian P, De Ugarte DA, Huang Jl, Mizuno H, et al. Human adipose tissue is a source of multipotent stem cells. Mol Bio Cell. 2002;13:4279-95.

23. Dominici MLBK, Le Blanc K, Mueller I, Slaper-Cortenbach I, Marini FC, Krause DS, et al. Minimal criteria for defining multipotent mesenchymal stromal cells. The International Society for Cellular Therapy position statement. Cytotherapy. 2006:8(4):315-7.

24. Qi Y, Sun L, Yang H. Lipid droplet growth and adipocyte development: mechanistically distinct processes connected by phospholipids. Biochim Biophys Acta Mol Cell Biol Lipids. 2017;1862(10):1273-83. 
25. Mohammadi Z, Afshari JT, Keramati MR, Alamdari DH, Ganjibakhsh M, Zarmehri AM, et al. Differentiation of adipocytes and osteocytes from human adipose and placental mesenchymal stem cells. Iran J Basic Med Sci. 2015;18(3):259.

26. Doucet C, Ernou I, Zhang Y, Llense JR, Begot L, Holy X, Lataillade JJ. Platelet lysates promote mesenchymal stem cell expansion: a safety substitute for animal serum in cell-based therapy applications. J Cell Physiol. 2005;205(2):228-36.

27. Mishra A, Tummala P, King A, Lee B, Kraus M, Tse V, Jacobs CR. Buffered platelet-rich plasma enhances mesenchymal stem cell proliferation and chondrogenic differentiation. Tissue Eng Part C Methods. 2009;15(3):431-5.

28. Chevallier N, Anagnostou F, Zilber S, Bodivit G, Maurin S, Barrault A. Osteoblastic differentiation of human mesenchymal stem cells with platelet lysate. Biomaterials. 2010;31:270-8.

29. Huang Jl, Zuk PA, Jones NF, Zhu M, Lorenz HP, Hedrick MH, Benhaim P. Chondrogenic potential of multipotential cells from human adipose tissue. Plast Reconstr Surg. 2004;113:585

30. Puetzer JL, Petitte JN, Loboa EG. Comparative review of growth factors for induction of three-dimensional in vitro chondrogenesis in human mesenchymal stem cells isolated from bone marrow and adipose tissue. Tissue Eng Part B Rev. 2010;16(4):435-44.

31. Lisignoli G, Cristino S, Piacentini A, Toneguzzi S, Grassi F, Cavallo C, et al. Cellular and molecular events during chondrogenesis of human mesenchymal stromal cells grown in a three-dimensional hyaluronan based scaffold. Biomaterials. 2005;26(28):5677-86.

32. Rosadi I, Karina Rl, Sobariah S, Afini I, Widyastuti T, Barlian A. The effect of human platelet-rich plasma and L-ascorbic acid on morphology, proliferation, and chondrogenesis ability towards human adipose-derived stem cells. Mol Cell Biomed Sci. 2019;3(1):26-33.

33. Kang YJ, Jeon ES, Song HY. Role of $\mathrm{c}$-Jun N-terminal kinase in the PDGFinduced proliferation and migration of human adipose tissue-derived mesenchymal stem cells. J Cell Biochem. 2005;95:1135-45.

34. Gentile P. Concise review: adipose-derived stromal vascular fraction cells and platelet-rich plasma: basic and clinical implications for tissue engineering therapies in regenerative surgery. Stem Cells Transl Med. 2012;1(3):230-6.

35. Palumbo S, Tsai TL, Li WJ. Macrophage migration inhibitory factor regulates AKT signaling in hypoxic culture to modulate senescence of human mesenchymal stem cells. Stem Cells Dev. 2014;23:852-65.

36. Atashi F, Jaconi ME, Pittet-Cuenod B, Modarressi A. Autologous platelet-rich plasma: a biological supplement to enhance adipose-derived mesenchymal stem cell expansion. Tissue Eng Part C Methods. 2014;21:253-62.

37. Mabvuure N, Hindocha S, Jordan D, Khan WS. Chondrogenesis and developments in our understanding. Curr Stem Cell Res Ther. 2012;7(4):243-59.

38. Gasimli L, Hickey AM, Yang B, Li G, dela Rosa M, Nairn AV, et al. Changes in glycosaminoglycan structure on differentiation of human embryonic stem cells towards mesoderm and endoderm lineages. Biochim Biophys Acta. 2014;1840(6):1993-2003.

39. Trujillo NA, Popat KC. Increased adipogenic and decreased chondrogenic differentiation of adipose derived stem cells on nanowire surfaces. Materials. 2014;7(4):2605-30

40. Lee HJ, Choi BH, Min BH, Park SR. Changes in surface markers of human mesenchymal stem cells during the chondrogenic differentiation and dedifferentiation processes in vitro. Arthritis Rheum. 2009;60(8):2325-32.

41. Ullah M, Eucker J, Sittinger $M$, Ringe J. Mesenchymal stem cells and their chondrogenic differentiated and dedifferentiated progeny express chemokine receptor CCR9 and chemotactically migrate toward CCL25 or serum. Stem Cell Res Ther. 2013;4(4):99.

42. Diaz-Romero J, Gaillard JP, Grogan SP, Nesic D, Trub T, Mainil-Varlet P. Immunophenotypic analysis of human articular chondrocytes: changes in surface markers associated with cell expansion in monolayer culture. J Cell Physiol. 2005;202(3):731-42.

43. Goldring MB. Chondrogenesis, chondrocyte differentiation, and articular cartilage metabolism in health and osteoarthritis. Ther Adv Musculoskelet Dis. 2012;4(4):269-85

44. Yakymovych I, Ten Dijke P, Heldin CH, Souchelnytskyi S. Regulation of Smad signaling by protein kinase C. FASEB J. 2001;15(3):553

45. Wicks SJ, Lui S, Abdel-Wahab N, Mason RM, Chantry A. Inactivation of smadtransforming growth factor $\beta$ signaling by $\mathrm{Ca} 2+-$ calmodulin-dependent protein kinase II. Mol Cell Biol. 2000;20(21):8103-11.

46. Ding $X$, Zhu M, Xu B, Zhang J, Zhao Y, Ji S, et al. Integrated trilayered silk fibroin scaffold for osteochondral differentiation of adipose-derived stem cells. ACS Appl Mater Interfaces. 2014;6(19):16696-705.
47. Leong MF, Chan WY, Chian KS, Rasheed MZ, Anderson JM. Fabrication and in vitro and in vivo cell infiltration study of a bilayered cryogenic electrospun poly (D, L-lactide) scaffold. J Biomed Mater Res A. 2010;94(4):1141-9.

48. Lee JB, Jeong SI, Bae MS, Yang DH, Heo DN, Kim CH, et al. Highly porous electrospun nanofibers enhanced by ultrasonication for improved cellular infiltration. Tissue Eng Part A. 2011;17(21-22):2695-702.

49. Jiang J, Carlson MA, Teusink MJ, Wang H, MacEwan MR, Xie J. Expanding twodimensional electrospun nanofiber membranes in the third dimension by a modified gas-foaming technique. ACS Biomater Sci Eng. 2015;1(10):991-1001.

50. Saha S, Kundu B, Kirkham J, Wood D, Kundu SC, Yang XB. Osteochondral tissue engineering in vivo: a comparative study using layered silk fibroin scaffolds from mulberry and nonmulberry silkworms. PLoS One. 2013;8(11):e80004.

51. Liu Y, Beyer A, Aebersold R. On the dependency of cellular protein levels on mRNA abundance. Cell. 2016;165(3):535-50.

52. Kozhemyakina $E$, Lassar AB, Zelzer E. A pathway to bone: signaling molecules and transcription factors involved in chondrocyte development and maturation. Development. 2015;142(5):817-31.

53. Wu M, Chen G, Li YP. TGF- $\beta$ and BMP signaling in osteoblast, skeletal development, and bone formation, homeostasis and disease. Bone Res. 2016;4:16009.

54. Thouverey C, Caverzasio J. Focus on the p38 MAPK signaling pathway in bone development and maintenance. Bonekey Rep. 2015:4:711-8.

55. Murray IR, Geeslin AG, Goudie EB, Petrigliano FA, LaPrade RF. Minimum information for studies evaluating biologics in orthopaedics (MIBO): plateletrich plasma and mesenchymal stem cells. JBJS. 2017;99(10):809-19.

56. Chahla J, Cinque ME, Piuzzi NS, Mannava S, Geeslin AG, Murray IR, et al. A call for standardization in platelet-rich plasma preparation protocols and composition reporting: a systematic review of the clinical orthopaedic literature. JBJS. 2017;99(20):1769-79.

\section{Publisher's Note}

Springer Nature remains neutral with regard to jurisdictional claims in published maps and institutional affiliations.
Ready to submit your research? Choose BMC and benefit from:

- fast, convenient online submission

- thorough peer review by experienced researchers in your field

- rapid publication on acceptance

- support for research data, including large and complex data types

- gold Open Access which fosters wider collaboration and increased citations

- maximum visibility for your research: over $100 \mathrm{M}$ website views per year

At $\mathrm{BMC}$, research is always in progress.

Learn more biomedcentral.com/submissions 